\title{
Analisis Saluran Distribusi Sarana Produksi Pertanian (Saprotan) Pupuk di Kabupaten Pamekasan
}

Campina Illa Prihantini ${ }^{\mathrm{a}}$, Lutfiyanto ${ }^{\mathrm{b}}$

${ }^{a}$ Fakultas Pertanian,Perikanan, dan Peternakan, Universitas Sembilanbelas November Kolaka , Kolaka- Sulawesi Tenggara, Indonesia. Email: campinailla26@gmail.com

${ }^{b}$ STIE Bakti Bangsa Pamekasan, Pamekasan-Jawa Timur, Indonesia. Email: lutfiyanto.kece@gmail.com

Article Info

\section{Article history:}

Received 5 Juli 2019

Received in revised form 2 Agustus 2019

Accepted 25 Agustus 2019

DOI

https://doi.org/10.32938/ag.v4i4.820

Keywords:

Saluran Distribusi

Sarana Produksi Pertanian

Pupuk

Kios Pertanian

\section{Abstrak}

Penelitian ini fokus terhadap sistem distribusi atau penyaluran sarana produksi pertanian(saprotan) pupuk di Kabupaten Pamekasan. Sarana produksi pertanian merupakan komponen utama yang penting dalam menyukseskan program pemerintah dalam bidang pertanian. Terlebih pada ketersediaan pupuk, baik pupuk bersubsidi maupun non-subsidi. Penelitian ini dilakukan di kabupaten Pamekasan dengan cara melakukan kegiatan pencacahan terhadap kios dan toko pertanian yang ada di seluruh Kabupaten Pamekasan. Hasil dari kegiatan pencacahan diperoleh bahwa jumlah kios seluruhnya, baik resmi maupun non-resmi adalah sejumlah 313 kios. Jumlah ini tentu sangat besar, terlebih dengan rata-rata kios sjumlah 24 kios per kecamatan. Ironisnya, permasalahan saprotan pupuk masih saja sering terjadi, khususnya dalam hal ketersediaan pupuk saat musim tanam. Penelitian ini diharapkan bisa menjadi dasar evaluasi dalam penetuan kebijakan ketersediaan sarana produksi pertanian pupuk di tingkat nasional. Hal ini tentu sangat berdampak kepada masyarakat, tidak hanya dalam bidang pertanian, namun juga sosial, ekonomi, dan kesehatan.

\section{Pendahuluan}

Pertanian merupakan sektor yang sangat penting bagi kehidupan masyarakat miskin pedesaan di Indonesia. Pengembangan sektor pertanian secara efektif diperkirakan dapat mengurangi kemiskinan. Salah satu cara yang dapat dilakukan adalah dengan melakukan penyediaan dan peningkatan akses yang lebih terhadap petani-petani miskin, baik pelayanan swasta dan publik Untuk mencapai hal ini, maka diperlukan adanya dukungan berupa kebijakan, pengaturan, lingkungan usaha yang kondusif, dan infrastruktur yang memadai di sektor pertanian.

Komoditas pangan dan hortikultura dinilai sebagai (1) suatu komoditas yang penting bagi sejumlah besar petani berpenghasilan rendah, (2) memilik potensi pertumbuhan, dan (3) menunjukkan tanda-tanda yang jelas bahwa potensi pertumbuhan ini akan mengarah untuk peningkatan pendapatan petani. Oleh karenanya, beberapa langkah penting perlu dilakukan dalam mengatasi isu-isu kemiskinan melalui pengidentifikasikan terhadap beberapa sub-sekto pertanian. Sub-sektor komuditas ini berada di bawah tinjauan konstan dan dapat berubah seiring waktu. Sebagai contoh, beberapa sub- sektor dapat putus karena kinerja yang buruk, sementara yang lainnya perlu ditambahkan untuk menggantikannya (Khairinisya 2011). Program-program yang disediakan oleh pemerintah seharusnya juga memperhatikan faktor keberlanjutan program, adalah dapat melihat dampak nyata bagi objek sasaran program (Sularno et al., 2016).

Salah satu permasalahan utama dalam peningkatan produktivitas komoditas pertanian adalah ketersediaan sarana produksi pertanian (saprotan) (Setyaningtyas, 2016). Selama ini, ketersediaan saprotan terkadang memberikan polemik bagi petani-petani yang akan melakukan kegiatan tanam, terlebih saprotan pupuk, baim pupuk bersubsidi maupun non-subsidi (Arung, 2015). Oleh karena itu, perlu dilakukan penelitian yang bertujuan untuk menganalisis saluran distribusi sarana produksi pertanian, selanjutnya disebut saprotan, dari produsen kepada konsumen akhir. Kegiatan penelitian ini penting dilakukan untuk dapat memahami distribusi saprotan pada tingkat pemasok dan pelanggan kios, yakni para petani. Hasil penelitian ini diharapkan dapat digunakan membantu berbagai pihak terkait (stakeholder) dalam penyediaan input pertanian agar dapat menyediakan saprotan yang lebih baik di masa mendatang (Moko et al., 2017).

\section{Metode}

Penilitian ini dilakukan di seluruh kios yang terdapat di Kabupaten Pamekasan. Kabupaten Pamekasan terdiri atas tiga belas kecamatan. Pemilihan kios yang akan digunakan sebagai kios cacahan adalah berdasarkan data dari Dinas Pertanian Kabupaten Pamekasan dan hasil penelurusan masyarakat sekitar. Jumlah kios yang telah tercacah adalah 313 kios, baik kios resmi maupun kios non-resmi. Kegiatan pencacahan dilakukan selama tiga bulan, dari bulan Februari hingga April 2019. Secara keseluruhan, waktu penelitian ini adalah enam bulan. Data yang digunakan dalam penelitian ini adalah data primer dan data sekunder. Data primer diperoleh dari hasil wawancara langsung dalam kuisioner. Data sekunder yang dibutuhkan dalam penelitian ini yaitu data-data yang terkait dengan daerah penelitian, data tentang perpukuan di Kabupaten Pamekasan, dan data lainnya yang berkaitan dengan sistem distribusi dan hilirisasi saprotan pupuk. Data ini diperoleh dari instansi terkait, berbagai pustaka seperti buku, jurnal, dan internet. Metode pengambilan contoh dalam penelitian ini dilakukan secara purposive dan snowballing sampling. Metode ini yang digunakan dalam pengambilan data primer adalah melalui wawancara dengan pemilik kios dan beberapa pihak yang memang kompeten dalam bidang ini. Pemilihan kios didasarkan pada transaksi aktif yang dilakukan oleh kios selama satu tahun terakhir.

\section{Analisis Deskriptif}

Analisis deskriptif merupakan salah satu metode penelitian yang lebih fokus untuk menjelaskan suatu isu, fenomena, fakta, ataupun sifat serta hubungan antar fenomena yang digambarkan secara sistematis, faktual, dan akurat. Analisis deskriptif diharapkan dapat menggambarkan keadaan subyek dan objek penelitian sekarang berdasakan fakta-fakta yang terjadi di lapang. Analisis deskriptif digunakan untuk menjelaskan kejadian yang sedang terjad di masyarakat di masa sekarang. Analisis deskriptif dilakukan dengan pengumpulan dan penyusunan data terlebih dahulu kemudian data dianalisis dan diinterpretasikan (Riduan, 2010). Analisis deskriptif-kualitatif dalam penelitian ini menggambarkan saluran distribusi saprotan pupuk yang selama ini berjalan di Kabupten Pamekasan. Selain itu, analisis ini juga digunakan untuk menganalisis bagaimana masing-masing lembaga distribusi menjalankan fungsinya dalam mendistribusikan saprotan pupuk. Analisis deskriptif dalam penelitian ini digunakan untuk menjawab pertanyaan penelitian mengenai bagaimana kondisi distribusi dan hilirisasi saprotan yang selama ini berjalan di Kabupaten Pamekasan

\section{Hasil dan Pembahasan}

\subsection{Definisi Saluran Distribusi Sarana Produksi Pertanian (saprotan)}

Definisi rantai distribusi menurut Taylor (2000) merupakan kegiatan yang kompleks dan membutuhkan berbagai fasilitas dan aktivitas termasuk di dalamnya produksi dan penyaluran produk, dari produsen ke konsumen akhir. Kegiatan distribusi juga meliputi perencanaan dan pengelolaan permintaan dan penawaran, kebutuhan bahan baku, produksi dan jadwal produksi, pergudangan, pengendalian persediaan, pengiriman dan pelayanan konsumen Sedangkan fasilitas yang diperlukan termasuk bangunan pabrik, pusat distribusi, pusat pelayanan, dan operasi eceran. Produk didistribusikan dengan menggunakan kereta api, truk, jaringan perpipaan, telepon atau dengan mengutus orang.

Pada umumnya sistem distribusi merupakan suatu sistem yang rumit. Hal yang membuat proses dan manajemen distribusi rumit adalah adanya ketidakpastian di sepanjang rantai pasokan dan dalam setiap tahap. Bentuk ketidakpastian ini dapat berupa kesalahan perkiraan, kelambatan pengiriman, rendahnya mutu bahan baku, rusaknya mesin dan peralatan, pembatalan pesanan, kesalahan informasi, kelambatan informasi dan berbagai kesalahan lain yang menyebabkan konsumen kesulitan mendapatkan produk sesuai dengan yang diinginkannya.

Oleh karena itu, agar manajemen distribusi efektif diperlukan kerjasama yang baik antara produsen dan konsumen dalam pola yang terkoordinas melalui pertukaran informasi dan komunikasi yang terbuka. Komunikasi in adalah merupakan aliran informasi yang rapat diantara konsumen, produsen, pusat distribusi, dan sistem transportasi yang memungkinkan perusahaan mengembangkan rantai distribusi yang efisien. Produsen dan konsumen harus mempunyai tujuan yang sama.

Keberhasilan distribusi sangat ditentukan oleh kemauan produsen dan distributor untuk menjalankan tugas masing-masing. Konsumumen sebagai pemakai akhir tentu akan sangat diuntungkan jika distribusi semakin lancar Tujuan dari distribusi barang ini menurut Kottler (1991) adalah agar perusahaan dapat menempatkan produknya pada tempat dan waktu yang tepat dengan biaya yang rendah agar harga produk juga dapat ditekan. Sedangkan Taylor (2000) menambahkan selain ketiga hal tersebut di atas juga agar kualitas produk yang diterima konsumen tetap dapat terjamin.

3.2. Kondisi Keterkinian Distribusi Saprotan Di Kabupaaten Pamekasan

Kios sarana produksi pertanian di Kabupaten terbagi atas menjadi dua berdasarkan legalitas kepemilikannya. Dikatakan kios legal atau kios resmi jika 
kios tersebut telah didaftarkan kepada Dinas Perdagangan Kabupaten Pamekasan dan memiliki izin resmi sebagai agen atau kios atau penyedia saprotan melalui kepemilikan Surat Izin Usaha Perdagangan (SIUP). Sedangkan kios ilegal atau kios tidak resmi merupakan kios atau agen atau toko yang tidak memiliki izin resmi sebagai agen atau kios atau penyalur sarana produksi pertanian (saprotan) pupuk. Biasanya kios tidak resmi berupa toko kelontong dekat pusat desa, dekat pasar, atau perorangan yang menjual dengan cara membeli kepada kios atau agen resmi. Kegiatan jual-beli ini sebenarnya ilegal, karena saprotan pupuk yang sebagian besar diperjualbelikan adalah pupuk bersubsidi. Seperti yang kita ketahui bahwa pupuk bersubsidi memang khusus untuk dijual kepada petani, dan atau kelompok tani yang telah mengajukan kebutuhan jumlah pupuk melalui Rencana Definitif Kebutuhan Kelompok (RDKK).

Kegiatan jual-beli saprotan pupuk di Kabupaten Pamekasan pada umumnya sama dengan kegiatan jual-beli saprotan pupuk di kabupaten lainnya. Artinya, sudah menjadi rahasia umum bahwa memang masih terdapat kegiatan jual-beli atau transaksi ilegal dalam penyaluran atau distribusi saprotan pupuk bersubsidi. Namun, tidak dapat dipungkiri bahwa kegiatan jual-beli ini juga meberikan dampak positif bagi pemenuhan kebutuhan petani gurem yang memang hanya membutuhkan jumlah pupuk yang relatif lebih rendah jumlahnya. Kedua, terdapat kasus dimana terdapat petani yang bekerja sebagai petani penggarap dalam sistem bagi hasil dalam suatu kegiatan usahatani. Petani penggarap biasanya seseorang yang bekerja sebagai petani di saat musim tanam tertentu saja. Pekerjaan utama mereka bukanlah petani sehingga tidak terdaftar sebagai anggota dalam sebuah kelompok tani. Alhasil, kebutuhan saprotan, baik pupuk, benih, maupun pestisida, dalam menjalankan usaha tani dengan sistem bagi hasil, dapat dipenuhi dengan membeli kepada kios tidak resmi.

Keberadaan kios tidak resmi juga mampu menggeliatkan kegiatan ekonomi dalam masyarakat. Meskipun kegiatan ekonomi yang mereka jalankan adalah illegal transaction, namun tidak dapat dipungkiri bahwa mereka dapat memutar kegiatan ekonomi pertanian di suatu desa. Sehingga keberadaan mereka bagai buah simalakama. Jika diberantas, mereka akan tetap muncul karena objek yang diperjualbelikan merupakan barang ekonomi yang permintaannya selalu ada. $0,40 \%$.

\section{Jumlah Kios Saprotan di Kabupten Pamekasan tahun 2018}

Kegiatan pencacahan kios sarana produksi pertanian (saprotan) bertujuan untuk mencacah berapa jumlah kios saprotan yang ada di lapang, baik kios resmi maupun kios tidak resmi. Produsen pupuk yang beredar di Kabupaten Pamekasan pada umumnya hanya ada dua, yakni PT Kaltim dan PT Petrokimia Gresik. Namun, produsen utama di Kabupaten Pamekasan adalah PT Petrokimia Gresik berdasarkan hasil wawancara dengan responden.

Tabel 1. Jumlah Kios Saprotan Per Kecamatan Kabupaten Pamekasan

\begin{tabular}{|c|c|c|c|c|c|c|}
\hline \multirow[b]{2}{*}{ No } & \multirow[b]{2}{*}{ Kecamatan } & \multicolumn{3}{|c|}{ Jumlah Kios } & \multirow[b]{2}{*}{$\begin{array}{l}\text { Non- } \\
\text { Resmi }\end{array}$} & \multirow[b]{2}{*}{ Jumlah } \\
\hline & & & $\begin{array}{c}\text { PT. } \\
\text { Kaltim }\end{array}$ & $\begin{array}{l}\text { PT. Petrokomia } \\
\text { Gersik }\end{array}$ & & \\
\hline 1 & Tlanakan & & 4 & 4 & 4 & 12 \\
\hline 2 & Pamekasan & & 4 & 4 & 3 & 11 \\
\hline 3 & Pademawu & & 3 & 7 & 6 & 16 \\
\hline 4 & Galis & & 7 & 11 & 15 & 33 \\
\hline 5 & Pegantenan & & 9 & 8 & 6 & 23 \\
\hline 6 & Proppo & & 11 & 11 & 16 & 38 \\
\hline 7 & Waru & & 4 & 4 & 6 & 14 \\
\hline 8 & Pasean & & 8 & 8 & 14 & 30 \\
\hline 9 & Palengaan & & 9 & 13 & 4 & 26 \\
\hline 10 & Pakong & & 6 & 6 & 13 & 25 \\
\hline 11 & Larangan & & 9 & 9 & 22 & 40 \\
\hline 12 & Batumarmar & & 12 & 12 & 7 & 31 \\
\hline \multirow[t]{2}{*}{13} & Kadur & & 7 & 7 & 6 & 20 \\
\hline & Jumlah Kios & & 93 & 104 & 116 & 313 \\
\hline \multicolumn{3}{|c|}{$\begin{array}{lll}\text { Rata-rata Kios } & \begin{array}{l}\text { Penyalur } \\
\text { Kecamatan }\end{array} & \begin{array}{l}\text { Per } \\
\text { (Kios }\end{array} \\
\text { Kecamatan) } & & \end{array}$} & 7 & 8 & 9 & 24 \\
\hline
\end{tabular}

Rata-rata Kios Penyalur Per

Desa (Kios Per Desa)

1,7

Sumber: Dinas Pertanian, Perkebunan, Peternakan Kabupaten Pamekasan (2018) dan Data Primer (2019)

Kegiatan pencacahan dilakukan selama kurang lebih tiga bulan. Kegiatan ini dimulai dengan mewawancarai petugas atau penyuluh pertanian di Dinas Tanaman Pangan dan Hortikultura Kabupaten Pamekasan. Data-data yang diberikan oleh narasumber adalah jumlah dan nama-nama kios resmi penyalur saprotan pupuk di Kabupaten Pamekasan. Berdasarkan hasil wawancara, diperoleh data jumlah kios resmi adalah 99 kios untuk penyalur PT Kaltim dan 104 kios untuk penyalur PT Petrokomia Gresik. Kemudian, peneliti melakukan pencacahan dengan turun ke desa yang ada di Kabupaten Pamekasan. Untuk mempermudah kegiatan pencacahan ini, peneliti melakukan wawancara kepada perangkat desa atau masyarakat desa tentang kios atau toko tempat penjualan saprotan. Hasil kegiatan pencacahan diperoleh jumlah kios tidak resmi adalah 116 kios. Sehingga jumlah kios penyalur sarana produksi pertanian (saprotan) pupuk di Kabupaten adalah sejumlah 313 kios. Data mengenai jumlah kios per kecamatan di Kabupaten Pamekasan dajikan dalam Tabel 1.

Berdasarkan data hasil pencacahan kios dalam Tabel 1, kecamatan dengan kios terbanyak adalah Kecamatan Proppo, terdiri atas 11 kios remi penyalur PT Kaltim, 11 kios resmi penyalur PT Petrokimia Gresik, dan 22 kios non-resmi. Kecamatan dengan kios paling kecil jumlahnya adalah Kecamatan Pamekasan, terdiri atas 4 kios resmi penyalur PT Kaltim, 4 kios resmi penyalur PT petrokimia Gresik, dan 3 kios non-resmi. Rata-rata jumlah kios per kecamatan adalah sebesar 7 kios resmi penyalur PT Kaltim, 8 kios resmi penyalur PT Petrokimia Gresik, dan 9 kios non resmi. Data ini diperoleh dengan cara membagi jumlah kios resmi penyalur PT Kaltim, PT petrokimia Gresik, dan kios non-resmi terhadap jumlah kecamatan yang ada di Kabupaten Pamekasan, yakni 13 kecamatan. Kemudian, rata-rata jumlah kios yang ada di setiap kecamatan, baik kios resmi maupun non-resmi adalah 24 kios. Data ini diperoleh dengan cara membagi jumlah seluruh kios terhadap jumlah kecamatan yang ada di Kabupaten Pamekasan.

Berdasarkan data dalam tabel 3, kecamatan dengan jumlah kio saprotan pupuk paling kecil jumlahnya adalah Kecamatan Pamekasan. Hal in disebabkan karena lahan pertanian dan perkebunan di kecamatan ini memang lebih kecil luas arealnya dibandingkan kecamatan lainnya (BPS Kabupaten Pamekasan, 2018). Sehingga, kebutuhan akan pupuk juga rendah. Hal ini berdampak terhadap jumlah kios penyalur saprotan pupuk yang juga kecil jumlahnya.

\section{Saluran Distribusi Saprotaan Di Kabupaten Pamekasan}

Seperti halnya produk hasil pertanian, sarana produksi pertanian (saprotan) pupuk juga memiliki saluran distribusi. Hal ini mejadi penting dalam kegiatan pertanian. Dalam proses penyaluran atau distribusi saprotan pupuk, terdapat banyak kendala dan permasalahn yang harus dihadapi. Terdapat tujuh lembaga distribusi yang memegang peranan penting dalam sistem distribysi saprotan pupuk di Kabupaten Pamekasan, yakni produsen, distributor, kios resmi, kios non-resmi, pengecer, petani, dan kelompok tani. Fungsi masing-masing lembaga distribusi disajikan dalam Tabel 1. Saluran distribusi saprotan pupuk disajikan dalam Gambar 1. Berdasarkan analisis saluran distribusi, terdapa enam saluran distribusi yang dapat terjadi. Saluran distribusi tersebut telah sesuai dengan apa yang selama ini terjadi di Kabupaten Pamekasan. Pada umumnya, system distribusi dan hilirisasi saprotan pupuk telah sesuai dengan Gambar 1

\section{Analisis Saluran Distribusi Saprotan Pupuk Di Kabupaten} Pamekasan

Berdasarkan Gambar 1, terdapat enam saluran distribusi saprotan pupuk di Kabupaten Pamekasan. Saluran-saluran distribusi tersebut dapat melalui kios resmi maupun non-rsmi. Berikut merupakan enam saluran distribusi saprotan pupuk yang selama ini memang berjalan di Kabupaten Pamekasan.

(1) Kantor Cabang $\rightarrow$ Distributor $\rightarrow$ Kios Resmi $\rightarrow$ Pengecer $\rightarrow$ Petani

(2) Kantor Cabang $\rightarrow$ Distributor $\rightarrow$ Kios Resmi $\rightarrow$ Pengecer $\rightarrow$ Kelompoktani $\rightarrow$ Petani

(3) Kantor Cabang $\rightarrow$ Distributor $\rightarrow$ Kios Resmi $\rightarrow$ Kios Non-Resmi $\rightarrow$ Pengecer $\rightarrow$ Petani

(4) Kantor Cabang $\rightarrow$ Distributor $\rightarrow$ Kios Resmi $\rightarrow$ Kios Non-Resmi $\rightarrow$ Pengecer $\rightarrow$ Kelompoktani $\rightarrow$ Petani

(5) Kantor Cabang $\rightarrow$ Distributor $\rightarrow$ Kios Resmi $\rightarrow$ Kios Non-Resm $\rightarrow$ Kelompoktani $\rightarrow$ Petani

(6) Kantor Cabang $\rightarrow$ Distributor $\rightarrow$ Kios Resmi $\rightarrow$ Kios Non-Resmi $\rightarrow$ Petani.

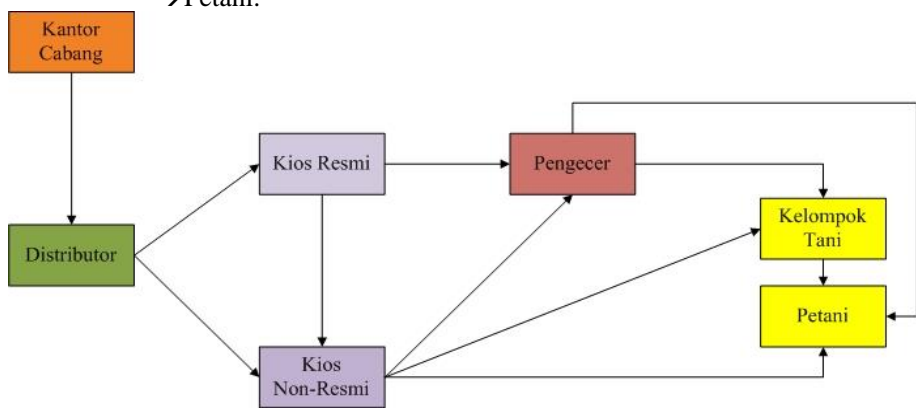

Gambar 1 Saluran Distribusi Pupuk Di Kabupaten Pamekasan

4. Analisis Fungsi Lembaga Distribusi Saprotan Di Kabupaten Pamekasan

Berdasarkan Gambar 1, lembaga distribusi pertama adalah Kantor Cabang. Kantor Cabang yang dimaksud dalam hal ini adalah perusahaan pupuk atau produsen pupuk, baik itu PT Kaltim maupun PT Petrokimia Gresik Lembaga ini berfungsi sebagai lembaga yang menyediakan saprotan pupuk. Setiap kabupaten memiliki kantor cabang resmi sebagai perwakilan di setiap 
kabupaten. Selanjutnya, saprotan tersebut disalurkan kepada distributor. Distributor akan melakukan penerbusan kepada kantor cabang. Lembaga ini melakukan fungsi pembelian kepada kantor cabang, melakukan fungsi penjualan kepada kios resmi dan non-resmi, fungsi distribusi kepada kios-kios, dan fungsi penyimpanan. Selanjutnya adalah kios resmi dan kios non-resmi. Kedua lembaga distribusi ini hanya terletak pada kepemilikan SIUP (Tabel 2). Fungsi yang mereka jalankan sama halnya dengan dungsi yang dijalankan oleh distributor. Hanya saja, jumlah yang mereka jual dalam skala yang lebih kecil (biasanya per zak). Menurut aturan yang berlaku, distributor diwajibkan untuk hanya menjual kepada kios atau agen resmi. Namun, terdapat beberapa oknum yang masih melakukan penjualan kepada kios non-resmi yang memang sifatnya diam-diam atau ilegal. Lembaga selanjutnya adalah pengecer. Pengecer ini juga sebenarnya lembaga yang melakukan transaksi ilegal. Hal ini disebabkan karena mereka tidak memiliki izin resmi dari pemerintah dan tidak memiliki SPJB (Tabel 2). Namun, tentu saja hal ini berbeda dengan di lapang. Selalu saja ada oknum yang memang bisa melakukan transkasi jual-beli di luar koridornya Fungsi dari lembaga ini sama halnya dengan fungsi yang dijalankan oleh distributor, kios resmi, dan kios non-resmi. Lembaga kelompoktani merupakan lembaga distribusi yang resmi memang sebagai lembaga penyalur saprotan pupuk. Lembaga ini bertugas untuk mendistribusikan saprotan pupuk kepada petani yang tergabung dalam kelompoktani. Lembaga ini mengajukan jumlah saprotan pupuk berdasarkan RDKK (Tabel 2). Petani yang tidak tergabung, biasanya juga termasuk petani gurem, tetap dapat melakukan transkasi distribusi saprotan pupuk. Lembaga ini melakukan transaksi yang juga dapat dikatakan ilegal. Karena seorang petani yang ingin membeli pupuk harus tergabung dalam suatu kelompoktani (Susilowati, 2017).

Pada beberapa kasus, keberadaan beberapa lembaga distribusi memang tidak sesuai dengan aturan main dunia perpupukan Indonesia. Namun, hal ini sudah menjadi rahasia bersama (Moko et al., 2017). Tanpa adanya black market, petani-petani yang tidak tergabung dalam kelompoktani mengalami kesulitan. Hal ini juga berpengaruh terhadap sistem sosial ekonomi masyarakat sekitar. Perekonomian menjadi tidak bergeliat. Hal ini tentu juga akan berpengaruh terhadap tingkat kesejahteraan masyarakat.

Tabel 2. Fungsi Lembaga Distribusi Dan Hilirisasi Saprotan Di Kabupaten Pamekasan

\begin{tabular}{|c|c|c|c|}
\hline No & $\begin{array}{l}\text { Lembaga } \\
\text { Distribusi }\end{array}$ & Definisi/Karakteristik & Fungsi Lembaga \\
\hline 1 & $\begin{array}{l}\text { Produsen } \\
\text { (Kantor } \\
\text { Cabang) }\end{array}$ & $\begin{array}{l}\text { Produsen pupuk, dalam hal ini PT } \\
\text { Petrokimia Gresik yang memproduksi } \\
\text { pupuk organik dan anorganik. }\end{array}$ & Fungsi Penyediaan \\
\hline 2 & Distributor & $\begin{array}{l}\text { Perusahaan perseorangan atau badan usaha, } \\
\text { baik yang berbentuk badan hukum yang } \mathrm{P} \\
\text { ditunjuk oleh produsen berdasarkan Surat } \\
\text { Perjanjian Jual Beli (SPJB) untuk } \\
\text { melakukan pembelian, penyimpanan, } \\
\text { penyaluran, dan penjualan Pupuk Bersubsidi } \\
\text { dalam partai besar di wilayah } \\
\text { tanggungjawabnya. }\end{array}$ & $\begin{array}{l}\text { Fungsi Pembelian, Fungsi } \\
\text { Penjualan, Fungsi Distribusi } \\
\text { Fungsi Penyimpanan }\end{array}$ \\
\hline
\end{tabular}

3 Kios Resmi Perusahaan perorangan atau badan usaha, Fungsi Pembelian, Fungsi baik yang berbentuk badan hukum yang Penjualan, Fungsi Distribusi, berkedudukan di Kecamatan dan/atau Desa, Fungsi Penyimpanan yang ditunjuk oleh Distributor berdasarkan Surat Perjanjian Jual Beli (SPJB) untuk melakukan penjualan Pupuk Bersubsidi secara langsung hanya kepada Kelompktani dan/atau Petani di wilayah tanggungjawabnya.

4 Kios Non-erusahaan perorangan atau badan usaha, Fungsi Pembelian, Fungsi Resmi baik yang berbentuk bukan badan hukum Penjualan, Fungsi Distribusi, yang berkedudukan di Kecamatan dan/atau Fungsi Penyimpanan Desa, yang ditunjuk oleh Distributor berdasarkan Surat Perjanjian Jual Beli (SPJB) untuk melakukan penjualan Pupuk Bersubsidi secara langsung hanya kepada Kelompktani dan/atau Petani di wilayah

\begin{tabular}{|c|c|c|}
\hline & Petani & $\begin{array}{l}\text { Perorangan WNI dan/atau beserta } \\
\text { keluarganya yang melakukan usahatani di } \\
\text { bidang tanaman pangan, hortikultura, } \\
\text { perkebunan, dan/atau peternakan. }\end{array}$ \\
\hline 6 & Pengecer & 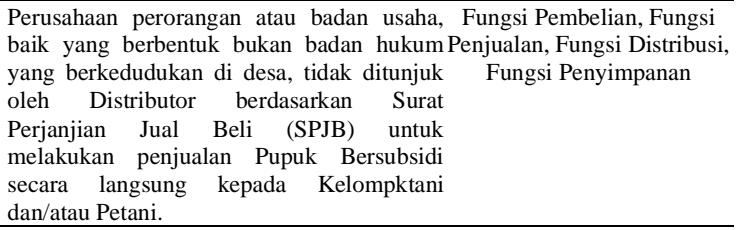 \\
\hline & $\begin{array}{l}\text { Kelompok } \\
\text { Tani }\end{array}$ & $\begin{array}{lll}\text { Kumpulan petani atau petambak yangFungsi Pembelian, } & \text { Fungsi } \\
\text { dibentuk atas dasar kesamaan kepentingan,Distribusi, } & \text { Fungsi } \\
\text { kesamaan kondisi lingkungan soial,Penyimpanan } & \\
\text { ekonomi, dan sumberdaya, kesamaan } & \\
\text { komuditas, dan keakraban untuk } & \\
\text { meningkatkan dan mengembangkan usaha } & \\
\text { anggotanya. } & & \\
& & \\
& & \\
\end{array}$ \\
\hline
\end{tabular}

Sumber : Ditjen PSP Kementan RI (2018), Data Primer (2019)

\section{Sebaran Wilayah Cakupan Distributor Saprotan Pupuk}

Masing-masing distributor memiliki wilayah cakupan masing-masing. Artinya, beberapa kecamatan dipegang oleh satu distribor. Pembagian wilayah cakupan ini didasarkan pada hasil rapat diskusi antara anggota Dewan Perwakilan Rakyat (DPR) dengan stakeholder terkait, seperti dari kantor cabang, para distributor, para agen atau kios resmi, Dinas Pertanian, Perkebunan, dan Peternakan Kabupaten Pamekasan, Dinas Perdagangan Kabupaten Pamekasan, dan Dewan Pengawas Pupuk Kabupaten Pamekasan. Sistem distribusi saprotan pupuk di Kabupaten Pamekasan dipegang oleh enam distributor, yakni UD tani Murni, UD Sugesty, CV Adi Candra Sumekar, CV Marta Indah Jaya, UD Vivafit, dan UD Gaya Masa. Berdasarkan hasil analisis, jumlah kios remi antara Tabel 1 dan Tabel 3 adalah sama, yakni 93 kios pada PT Petrokima Gresik dan 104 kios pada PT Kaltim. Kemudian, ada beberapa distributor yang memang hanya menjadi supplier arau penyalur salah sarau produesn. Misalnya, CV Adi Candra Sumekar dan CV Gaya Masa hanya menjadi supplier pada PT Petrokimia Gresik, sedangkan UD Vivafit hanya menjadi supplier pada PT Kaltim saja. Terdapat pertanyaan, apakah distributor ini hanya medistribusikan saprotan pupuk pada kios resmi? Jawabannya tidak. Faktanya di lapang, mereka (distributor resmi) juga ikut andil dalam kegiatan black market. Artinya, mereka juga ikut mendistribusikan kepada kios nonresmi. Tentunya, kegiatan ini memang sudah di luar koridor dan hal ini memang sangat sulit untuk dicegah. Yang bisa dilakukan hanyalah meminimalisirnya. Namun, tidak dapat dipungkiri bahwa kegiatan ini mampu menggeliatkan gaerah perekonomian di daerah (Windari 2016, Khairunisya 2011). Jadi, sangat sulit untuk membinasakan atau menghilangkan praktikpraktik seperti contoh di atas.

Tabel 3. Sebaran Wilayah Cakupan Distributor Saprotan Pupuk Di Kabupaten Pamekasan

\begin{tabular}{|c|c|c|c|c|c|c|c|}
\hline \multirow[t]{2}{*}{ No. } & \multirow{2}{*}{$\begin{array}{c}\text { Nama } \\
\text { Distributor }\end{array}$} & \multicolumn{4}{|c|}{ Wilayah Cakupan } & \multicolumn{2}{|c|}{ Jumlah Kios Resmi } \\
\hline & & PT & $\begin{array}{l}\text { Petrokimia } \\
\text { Gresik }\end{array}$ & & PT. Kaltim & $\begin{array}{c}\text { PT. } \\
\text { Petrokimia } \\
\text { Gresik }\end{array}$ & $\begin{array}{c}\text { PT. } \\
\text { Kaltim }\end{array}$ \\
\hline \multirow{3}{*}{\multicolumn{2}{|c|}{ 1. UD. Tani }} & $\mathrm{i}(1)$ & Pakong & (1) & Pakong & 6 & 6 \\
\hline & & (2) & Waru & (2) & Waru & 4 & 4 \\
\hline & & (3) & Batumarmal & $\operatorname{rr}(3)$ & Pasean & 12 & 8 \\
\hline \multirow[t]{6}{*}{2.} & UD. Sugesty & (1) & Pamekasan & (1) & Pamekasan & 4 & 4 \\
\hline & & (2) & Pademawu & (2) & Galis & 11 & 7 \\
\hline & & (3) & Galis & (3) & Pademawu & 11 & 7 \\
\hline & & & & (4) & Palengaan & & 9 \\
\hline & & & & (5) & Pegantenan & & 9 \\
\hline & & & & (6) & Batumarmar & & 12 \\
\hline \multirow[t]{3}{*}{3.} & CV. Adi Candr: & (1) & Proppo & - & & 4 & - \\
\hline & Sumekar & (2) & Palengaan & & & 13 & \\
\hline & & (3) & Pegantenan & & & 8 & \\
\hline \multirow[t]{2}{*}{4.} & CV. Marta & (1) & Tlanakan & (1) & Tlanakan & 4 & 4 \\
\hline & Indah Jaya & (2) & Pasean & (2) & Proppo & 8 & 4 \\
\hline \multirow[t]{2}{*}{5.} & UD. Vivafit & - & & (1) & Larangan & - & 9 \\
\hline & & & & (2) & Kadur & & 7 \\
\hline \multirow{2}{*}{\multicolumn{2}{|c|}{ CV. Gaya Masa }} & $(1)$ & Larangan & - & & 9 & - \\
\hline & & (2) & Kadur & & & 7 & \\
\hline \multicolumn{6}{|c|}{ Jumlah Kios Resmi } & 104 & 93 \\
\hline
\end{tabular}

Sumber : Dinas Pertanian, Perkebunan, Peternakan Kabupaten Pamekasan (2018)

\section{Simpulan}

Hasil utama dari kegiatan pencacahan kios sarana produksi pertanian adalah bahwa terdapat 313 kios yang tersebar di seluruh Kabupaten Pamekasan. Rata-rata jumlah kios per kecamatan adalah 24 kios. Saluran distribusi yang umum dilakukan di Kabupaten Pamekasan adalah enam saluran. Masingmasing melibatkan minimal 4 lembaga distribusi. Kegiatan pencacahan ini diharapkan dapat menjadi bahan evaluasi dalam mengatasi permasalahan ketersediaan pupuk saat musim tanam. Biasanya, kelangkaan pupuk terjadi saa para petani akan mulai memasuki dan/atau musim tanam sedang berlangsung. Entah memang terdapat unsur kesengajaan atau tidak. Yang pasti, distribusi psaprotan pupuk sangat bergantung terhadap keberadaan lembaga-lembaga distribusi ini, terlebih kios-kios resmi dan non-resmi.

\section{Pustaka}

[BPS] Badan Pusat Statistik Kabupaten Pamekasan. 2018. Kabupaten Pamekasan Dalam Angka. Pamekasan(ID) : BPS Kabupaten Pamekasan.

[Ditjen PSP] Direktorat Jenderal Prasarana dan Sarana Pertanian Kementerian Pertanian. 2018. Petunjuk Pelaksanaan Penyediaan dan Penyaluran Pupuk Bersubsidi Tahun Anggaran 2018. Jakarta(ID) : Kementerian Pertanian.

Dinas Pertanian, Perkebunan, Peternakan Kabupaten Pamekasan. 2018. Data Distributor dan Kios Resmi Penyalur Pupuk Bersubsidi Kabupaten Pamekasan. Pamekasan(ID) : Dinas Pertanian, Perkebunan, Peternakan Kabupaten Pamekasan.

Arung J. 2015. Persepsi Masyarakat Kelompok Tani Tentang Penyaluran Pupuk Di Desa Long Lebusan Kecamatan Sungai Boh Kabupaten Malinau. Jurnal Pemerintahan Integratif. 3(2) : 375-391. 
Khairunisya. 2011. Efektivitas Penyaluran Pupuk Bersubsidi Bagi Petani Padi Di Kabupaten Lampung Tengah Tahun 2009 (Studi Kasus : Lini IV Kecamatan Trimurjo) [Skripsi]. Lampung(ID): Universitas Lampung.

Kotler, Philip. 2000. Marketing Management. Edisi Milenium. Prentice Hall Intl. Inc New Jersey.

Moko, Koko Widyat, Suwarto, dan Utami, Bekti Wahyu. 2017. Persepsi Petani Terhadap Program Kartu Tani Di Kecamatan Kalijambe Kabupaten Sragen.

Riduan, 2010, Metode \& Teknik Menyusun Proposal Penelitian, Bandung: Alfabeta.

Setyaningtyas, Myfa Nurul. 2016. Strategi Pengembangan Tanaman Pangan Guna Meningkatkan Perekonomian Kabupaten Kebumen. Economics Development Analysis Journal, 5(2) : 170-178.

Sularno, Irawan, Bambang, dan Handayani, Nida. 2016. Analisis Pelaksanaan Kebijakan Dan Distribusi Pupuk Bersubsidi Di Kabupaten Karawang Jawa Barat. Jurnal Agrosains dan Teknologi, 1(2) : 73-87.

Susilowati, Dwi. 2017. Efektivitas Sistem Distribusi Pupuk Di Kabupaten Malang. Ekonomika-Bisnis, 2(2) : $409-430$.

Taylor Bernard W \& Russell Roberta. 2000. Operations Management. Third Edition. Prentice Hall. New York.

Windari, Rizky Alifia dan Winandi, Ratna. 2016. Analisis Sistem Distribusi Pupuk Bersubsidi PT Pupuk Kujang Cikampek [Skripsi]. Bogor(ID) : Institut Pertanian Bogor. 